\title{
MOLECULAR STRUCTURE OF GELATIN EXTRACTED FROM PARROT (Scarus sp) FISH SCALES
}

Jeszy Novianti Andakke1, Hizkia H.Y. Nainggolan', Lasma R.M.E. Parapat ${ }^{1}$, Inneke F.M.Rumengan', Engel Pandey², Pipih Suptijah ${ }^{3}$, Aldian H.Luntungan ${ }^{4}$

1 Marine Science Study Program, Faculty of Fisheries and Marine Science, Sam Ratulangi University Manado

2 Fish Processing Technology Study Program, Faculty of Fisheries and Marine Science, Faculty of Fisheries and Marine Science, Sam Ratulangi University Manado

3 Fish Processing Technology Study Program, Faculty of Fisheries and Marine Science, Bogor Agricultural University

4 Post Graduated of Sam Ratulangi University Manado

*corresponding author:_ innekerumengan@unsrat.ac.id

\section{Abstract}

One of the protein molecules of fish scales is water soluble gelatin. Gelatin of fish scales could be best substitute of commercial available gelatin which derived from porcine and bovine. The purpose of this study was to determine the molecular structure of gelatin extracted from marine fish scale using Fourier transform infrared (FTIR) analysis, and to obtain the moisture content, $\mathrm{pH}$ and yield of gelatin. Samples were prepared from the wet and dried scales. As for the standard gelatin, the gelatin of the two samples are characterized with several types of amide groups. The two gelatin samples were slight different in absorption of wave length for amide A, B, I, II and III groups indicating the instability of the functional groups which may influence viscosity and gel strength. For the wet scales derived gelatin, the wave number absorption was found to be $3412 \mathrm{~cm}^{-1}$ (amide A), $2421 \mathrm{~cm}^{-1}$ (amide B), $1653 \mathrm{~cm}^{-1}$ (amide I), $1400 \mathrm{~cm}^{-1}$ (amide II), and $1001 \mathrm{~cm}^{-1}$ (amide III), while for the dried scales derived gelatin was $3435 \mathrm{~cm}^{-1}$ (amide A), $2920 \mathrm{~cm}^{-1}$ (amide B), $1635 \mathrm{~cm}^{-1}$ (amide I), $1404 \mathrm{~cm}^{-1}$ (amide II), and $1036 \mathrm{~cm}^{-1}$ (amide III). The wave number absorption of amide III of gelatin is smaller than the one of collagen, because gelatin is in form of single helix, not triple helix. The wet scales derived and dried scales derived gelatin show the moisture content of $15.0 \%$ and $13.7 \%$, and yield of $2.33 \%$ and $2.43 \%$, respectively. For both samples, the pH value was 7 .

Key words : gelatin, fish scales, molecule structure, moisture, yield, $\mathrm{pH}$

\section{Abstrak}

Salah satu dari molekul protein sisik ikan adalah gelatin larut air. Gelatin sisik ikan dapat menjadi pengganti terbaik dari gelatin komersial yang tersedia yang berasal dari babi dan sapi. Tujuan dari penelitian ini adalah untuk menentukan struktur molekul gelatin yang diekstrak dari sisik ikan laut menggunakan Analisis FTIR (Fourier Transform Infrared), dan untuk mendapatkan kadar air, pH dan rendemen gelatin. Sampel disiapkan dari sisik basah dan sisik kering. Adapun standar gelatin, gelatin dari kedua sampel ditandai dengan beberapa jenis gugus amida. Kedua sampel gelatin sedikit berbeda dalam penyerapan panjang gelombang untuk amida A, B, I, II dan III yang menunjukkan ketidakstabilan kelompok fungsional yang dapat mempengaruhi viskositas dan kekuatan gel. Untuk gelatin sisik basah, panjang gelombang serapan ditemukan pada $3412 \mathrm{~cm}^{-1}$ (amida A), $2421 \mathrm{~cm}^{-1}$ (amida B), $1653 \mathrm{~cm}^{-1}$ (amida I), 1400 $\mathrm{cm}^{-1}$ (amida II), and $1001 \mathrm{~cm}^{-1}$ (amida III), sedangkan untuk gelatin sisik kering adalah $3435 \mathrm{~cm}^{-1}$ (amida A), $2920 \mathrm{~cm}^{-1}$ (amida B), $1635 \mathrm{~cm}^{-1}$ (amida I), $1404 \mathrm{~cm}^{-1}$ (amida II), and $1036 \mathrm{~cm}^{-1}$ (amida III). Panjang gelombang serapan amida III pada gelatin lebih kecil dibanding kolagen, sehingga gelatin berbentuk single helix, bukan triple helix. Gelatin sisik basah dan sisik kering mengadung kadar air 15,0\% dan 13,7\%, rendemen $2,33 \%$ and $2,43 \%$, secara berturut-turut. Untuk kedua sampel memiliki nilai pH 7.

Key words : gelatin, sisik ikan, struktur molekul, kadar air, rendemen, $\mathrm{pH}$ 


\section{Introduction}

Gelatin is commercially used for food industry as a stabilizer, thickener, emulsifier, jelly formed, water binder, and settling down, while for pharmaceuticals industry it can be used as major material in capsule preparation (Damanik, 2005). In addition, gelatin could be prepared as a biodegradable matrix material in implantable delivery systems and microencapsulation of drugs (Rowe et al., 2009). Gelatin is chemically obtained by partial denaturation of the fibrous protein of collagen by heating in acid or alkaline $\mathrm{pH}$ (Haug and Draget, 2011; Lassoued et al, 2014).

Product of gelatin from pigskin is the highest (44\%), followed by bovine hides $(28 \%)$, bovine bones $(27 \%)$ and other sources (1\%) (Ahmad and Benjakul, 2011). However, the use of gelatin from pig and bovine sources have been problematic due to religious concerns (Nagarajan et al., 2012). A new source of gelatin can be obtained from marine fish scales. Fish scales are abundantly available as wastes of fish processing, especially in Manado, North Sulawesi which popularly known as a city surrounding with seafood restaurants. Parrot fish is one of the preferred marine fish species in various restaurants, and this fish was sold after removing the scales in local markets. Rumengan et al. (2017) have reported that parrot fish scale containing $32.30 \%$ of protein and it can be a potential sources of gelatin and can be accept by Islam, Judaism and Hinduism. The objectives of this study were to determine the molecular structure of gelatin from fish scale using FTIR analysis and detecting the functional group of gelatin by wave number absorption comparing to gelatin standard.

\section{Materials and Method}

Fish scales were obtained from local markets, and samples were immediately washed with running tap water. The scales processed in Laboratory of Molecular
Biology and Marine Pharmaceutical, Faculty of Fisheries and Marine Science, Sam Ratulangi University since march 13, 2019. The scales were cut into pieces and soaked in $\mathrm{NaOH} 0,5 \mathrm{~N}$ and distilled water for 48 hours to remove non-gelatinous protein. After soaking treatment, scales were washed with running water until $\mathrm{pH}$ of 7 . The scales were soaked in $\mathrm{HCl} 0,75 \%$ and distilled water for 24 hours, and again neutralized with running water until $\mathrm{pH}$ of 7 . Extraction procedure was conducted by heating the samples at $80^{\circ} \mathrm{C}$ for 3 hours, and then cooling at room temperature. Fourier transform infrared (FTIR) analysis was adopted from Khan et al. (2002) and Xu et al. (2005) method and moisture content from Gelatine Manufacture's Institute of America (GMIA) standard 2012. The yield of the dried scales derived gelatin was calculated using Equation 1.

Yield $(\%)=$ (weight of dried gelatin/weight of dried fish scale) $\times 100$

Result and Discussions
Molecular structure of gelation is
characterized by certain functional groups
which could be detected by absorption in the
wave number region. Figure 1 shows the
wave number absorption of the two samples,
wet and dried scales derived gelatin. The two
gelatin samples were slight different in
absorption of wave length for amide A, B, I,
II and III groups indicating the instability of
the functional groups which may influence
viscosity and gel strength. For the wet scales
derived gelatin, the wave number absorption
was found to be $3412 \mathrm{~cm}^{-1}$ (amide A), 2421
$\mathrm{~cm}^{-1}$ (amide B), $1653 \mathrm{~cm}^{-1}$ (amide I), $1400 \mathrm{~cm}$
1 (amide II), and $1001 \mathrm{~cm}^{-1}$ (amide III), while
for the dried scales derived gelatin was 3435
$\mathrm{~cm}^{-1}$ (amide A), $2920 \mathrm{~cm}^{-1}$ (amide B), 1635
$\mathrm{~cm}^{-1}$ (amide I), $1404 \mathrm{~cm}^{-1}$ (amide II), and
$1036 \mathrm{~cm}^{-1}$ (amide III), where the standard of
wave number absorption is presented in
Table 1.
Table 1. 


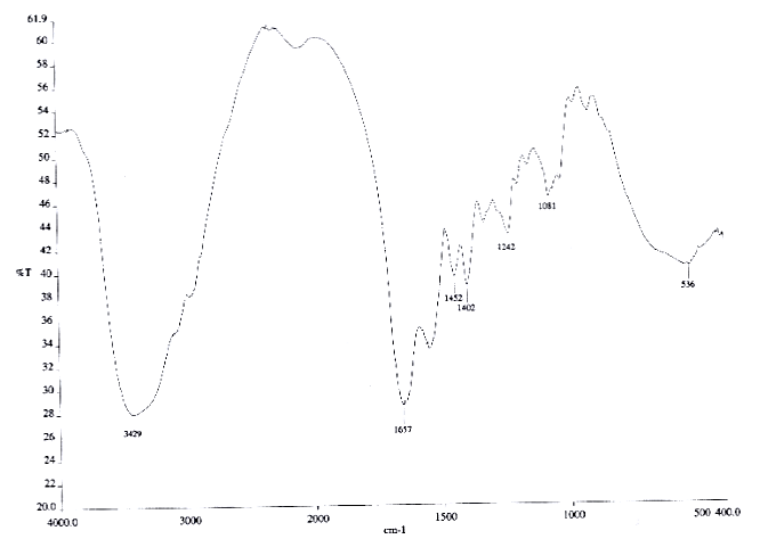

A

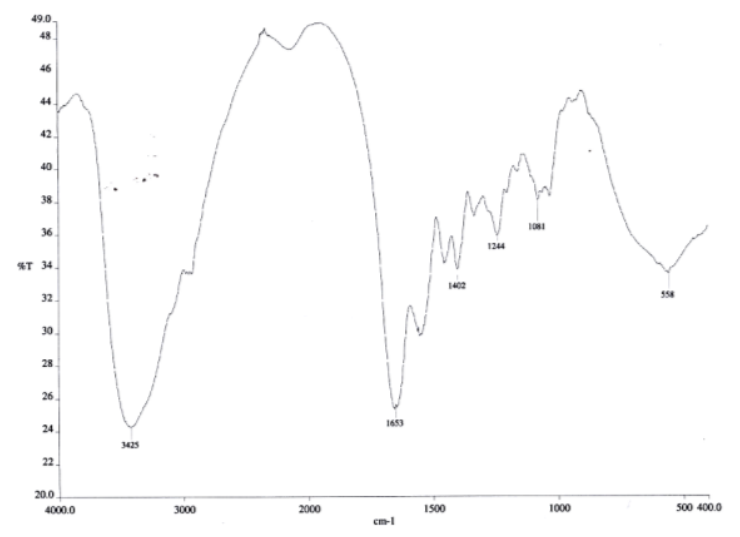

B

Figure 1. Wave number absorption of the wet scales derived gelatin $(A)$ and the dried scales derived gelatin $(B)$

Table 1. Absorption region of gelatin derived from fish scales $\left(\mathrm{cm}^{-1}\right)$

\begin{tabular}{lcccl}
\hline $\begin{array}{c}\text { Type of } \\
\text { Amida }\end{array}$ & Gs.wet & Gs.dry & $\begin{array}{c}\text { Absorption region of } \\
\text { Gelatin Standard }\end{array}$ & \multicolumn{1}{c}{ Note } \\
\hline Amide A & 3412 & 3435 & $3478-3310$ & $\mathrm{NH}$ streching \\
Amide B & 2421 & 2920 & $2935-2915$ & Asymmetric $\mathrm{CH}_{2}$ \\
Amide I & 1653 & 1635 & $1658-1653$ & $\mathrm{C}=\mathrm{O}$ stretching \\
Amide II & 1400 & 1404 & $1575-1480$ & $\mathrm{NH}$ CN stretching, bending \\
Amide III & 1001 & 1036 & $1240-1234$ & $\mathrm{NH}_{2}$ bending CN streching \\
\hline
\end{tabular}

Low peak of Amide III band was caused by the loss of triple helix while extraction process denaturation (Hashim et al., 2010). According to Muyonga et al (2004), the Amide III band intensity is responsible for the triple helix structure. The amide III absorption of gelatin is smaller than collagen amide III because the gelatin not producing triple helix but become a single helix. As explained by Kong and Yhun (2007) that the a helix component was shown in the gelatin absorption region at wave number of $1658-1653 \mathrm{~cm}^{-1}$. Therefore, the gelatin of parrot fish scales shows a helix structure that corresponds to the $\alpha$ helix. The amide II band functional group of gelatin parrot fish scales was found in gel soluble in wave absorption number of 1400-1404 $\mathrm{cm}^{-1}$ are closely related in this case the triple helix structure. The range absorption number in the area of $3478-3310 \mathrm{~cm}^{-1}$ indicates the presence of $\mathrm{NH}$ Stretching bonds on hydrogen bonds of amide groups. Parallel polarized absorption with $\mathrm{N}-\mathrm{H}$ bonds which are parallel to the $\alpha$-helix and perpendicular to the polypeptide chain on the b-sheet bond. The absorption at wave number of 1658$1653 \mathrm{~cm}^{-1}$ shows the carbonyl bond $\mathrm{C}=\mathrm{O}$ stretching with the contribution of $\mathrm{NH}$ and $\mathrm{CN}$ stretching bonds which are often referred as Amide I band. In the frequency range of $1575-1480 \mathrm{~cm}^{-1}$ there was an absorpt which shows the amide II group with a-helical structure and b-sheet structure. Amide II band calibration is caused by deformation of the $\mathrm{N}-\mathrm{H}$ bond. Absorption wave number of gelatin from parrot fish scale was suitable with the standard absorption number of gelatin where the amide I and II must be low intensity peaks and amide III peaks must be almost doesn't exist. 
Table 2. The moisture content, $\mathrm{pH}$ and yield of the wet scales derived gelatin (Gs.wet) and the dried scales derived gelation (Gs.dry) compared to the standard Gelatine Manufacture's Institute of America (GMIA)

\begin{tabular}{lccc}
\hline \multicolumn{1}{c}{ Items } & Gs.wet & Gs.dry & GMIA Standard 2012 \\
\hline $\begin{array}{l}\text { Moisture content } \\
\text { (\%bb) }\end{array}$ & $15.0 \%$ & $13.7 \%$ & $8-15 \%$ \\
pH & 7 & 7 & $3.8-7.5$ \\
The yield (\%bb) & $2.33 \%$ & $2.43 \%$ & - \\
\hline
\end{tabular}

As seen in Table 2, the moisture content of the wet scales derived gelatin was higher than the one of the dried scales derived gelatin and both of them are almost similar to the standard Gelatine Manufacture's Institute of America (GMIA). Low moisture determine the quality of gelatin. The lower the moisture content, the more concentrated gelatin produced. The $\mathrm{pH}$ value of the extracted gelatin from parrot fish's scales founds neutral $\mathrm{pH}(\mathrm{pH} 7)$. The different of $\mathrm{pH}$ value is influenced by neutralization process. Zhou and Regenstein (2005) reported that mixed acidic and alkalic treatments in the extraction process resulted in neutral $\mathrm{pH}$. The extraction yield of the dried scales derived gelatin was higher than the one of the wet scales derived gelatin.

\section{Conclusion}

Absorption of wave number of gelatin from parrot fish scale was in range of the one of the standard gelatin, which was characterized by several types of amide group. There was only minor diffences in the wave number absorption of the amide groups between the wet scales derived gelatin and the dried scales derived gelatin. The absorption wave number of amide III group for gelatin is smaller than the one of collagen indicating the molecular structure of gelatin is in single helix form, not triple helix.

\section{Acknowledgment}

The authors gratefully acknowledge funding received from Ministry of Research, Technology and Higher Education with scheme Student Creativity Program 2019.

\section{References}

[GMIA] Gelatine Manufacture's Institute of America. 2012. Gelatine Handbook. New York, USA: Published by Gelatine Manufacture's Institute of America, Inc.

Ahmad, M. and Benjakul, S. 2011. Characteristics of gelatin from the skin of unicorn leatherjacket (Aluterus monoceros) as influenced by acid pretreatment and extraction time. Food Hydrocolloids 25(3): 381-388.

Damanik, A. 2005. Gelatin Halal, Gelatin Haram. Jurnal Halal LPPOM MUI No.36 Maret 2001. Jakarta.

Hashim DM, CheMan YB, Norakasha $R$, Suhaimi M, Salmah $Y$, \& Syahariza ZA. (2010). Potential use of fourier transform infrared spectroscopy for differentiation of bovine and porcine gelatins. Food Chemistry, 118(3), 856860

Haug, I. J. and Draget, K. I. 2011. Gelatin. In Phillips, G. O. and Williams, P. A. (Eds). Handbook of Food Proteins, $p$ 98-115. Norway: Norwegian University of Science and Technology (NTNU). commercial halal bovine gelatin. Food Hydrocolloids 41: 309-318.

Khan. T. A., Peh, K. K., Ch'ng. H. S 2002 Reporting degree of deacetylation values of chitosan: the influence of analytical methods. Journal Pharmaceutical Science. 5(3), 205-212 pp. [9] 
Lassoued, I., Jridi, M., Nasri, R., Dammak, A., Hajji, M., Nasri, M. and Barkia, A. 2014. Characteristics and functional properties of gelatin from thornback ray skin obtained by pepsin-aided process in comparison with commercial halal bovine gelatin. Food Hydrocolloids 41: 309-318.

Rowe, R.C., Sheskey, P.J. and Quinn, M.E. 2009. Handbook of Pharmaceutical Excipients. 6th ed. Washington: Pharmaceutical Press and American Pharmacist Association.

Rumengan, I.F.M., P. Suptijah, S. Wullur, andA.Talumepa.2017.Characterization of chitin extracted from fish scales of marine fish special purchased from local markets in North Sulawesi, indonesia. IOP Conf. Series : Earth and Enviromental Science. Do i : 10.1088/1755-1315/89/101/2018
Nagarajan, M., Benjakul, S., Prodpran, T., Songtipya, P. and Kishimura, H. 2012. Characteristics and functional properties of gelatin from splendid squid (Loligo formosana) skin as affected by extraction temperatures. Food Hydrocolloids 29: 389-39

Xu Y.X., K.M. Kim, M.A. Hanna, and D. Nag 2005 Chitosan-starch composite film:preparation and characterization. Industrial Crops and Products 21. 185$192 \mathrm{pp}$.

Zhou P, Regenstein JM. 2005. Effects of alkaline and acid pretreatments on Alaska Pollock skin gelatin extraction. Journal of Food Science 70(6): 392396 